\title{
Utility of distant indirect ophthalmoscopy as screening tool in a case of pellucid marginal degeneration
}

\author{
Amber Amar Bhayana 지 , Manpreet Kaur, Shorya Vardhan Azad, Anshida Kalangottil
}

Ophthalmology, Dr Rajendra Prasad Centre for Ophthalmic Sciences, All India Institute of Medical Sciences, New Delhi, Delhi, India

\section{Correspondence to} Dr Shorya Vardhan Azad; shoryaazad@hotmail.com

Accepted 19 August 2020

Check for updates

(c) BMJ Publishing Group Limited 2020. No commercial re-use. See rights and permissions. Published by BMJ.

To cite: Bhayana $\mathrm{AA}$, Kaur M, Azad SV, et al. BMJ Case Rep 2020;13:e238787. doi:10.1136/bcr-2020238787

\section{DESCRIPTION}

A bedside ophthalmic consultation was sought for a 50-year-old woman with diabetes and hypertension admitted for cerebrovascular accident with a history of gradually progressive painless diminution vision in the right eye (RE) over the past 10 years. Bedside assessment of visual acuity (wearing level II personal protective equipment) revealed $1 / 60$ and $>6 / 60$ in $\mathrm{RE}$ and left eye (LE), respectively. Torch light examination was normal. Distant indirect ophthalmoscopy at $50 \mathrm{~cm}$ showed localised pear-shaped reflex in the inferior half of RE compared with a diffuse bright uniform glow in LE (figure 1A,B). No signs of retinopathy were noted on funduscopy in either eye. A presumptive diagnosis of RE irregular corneal astigmatism suggestive of inferior ectasia was made. Need for corneal topography was advised. Following a routine COVID-19 test which came out negative, the patient visited ophthalmology outpatient department (OPD) for a complete work-up post-systemic stabilisation. Best corrected visual acuity was $1 / 60$ and $6 / 6$ in RE and LE, respectively. Autorefraction (TONOREF 3, Nidek) of RE showed distorted and localised crowding of mires in the horizontal meridian (at 4 o'clock and 8'o clock radii specifically) indicating asymmetrical steepening with against the rule astigmatism (figure 1C). Anterior segment examination on slit lamp revealed localised thinning in the inferior part of cornea in RE. LE was unremarkable. Corneal topography done on Pentacam (OCULUS, Arlington, Washington, USA), revealed inferior thinning with crab-claw pattern in RE and minimal against the rule astigmatism with evolving crab-claw pattern in LE (figure 2). A diagnosis of unilateral pellucid marginal degeneration (PMD) in RE with subclinical PMD in LE was made. The patient was advised for a rigid gas-permeable contact lens trial for visual rehabilitation.

Pellucid marginal degeneration is a rare bilateral idiopathic non-inflammatory non-hereditary ectatic disorder which involves thinning of the inferior peripheral cornea without any form of scarring, vascularisation or lipid deposition. It occurs in both men and women and starts presenting around middle age. ${ }^{12}$ The diagnosis is based on corneal topography which demonstrates crab-claw pattern of steepened cornea in the inferior para-central meridians (most commonly 4 o'çlock and 8 o'clock) just above a band of thinned cornea. ${ }^{3}$
Ophthalmologists and ophthalmic practice have been severely affected by the COVID-19 pandemic. Often, comprehensive ophthalmic evaluation and testing may not be feasible due to proximity (to patient) required for proper assessment. ${ }^{4-7}$ Various advisories w.r.t. do's and don'ts in an ophthalmic OPD have proposed curtailed examination to prevent spread of the virus. In the current state, indirect ophthalmoscopy for fundus evaluation has been found acceptable and safer as compared with direct ophthalmoscopy and slit lamp examination as it allows adequate distancing from patient. ${ }^{8}$

Retroillumination and retinoscopy-based signs have been described for the diagnosis of central corneal ectasia, including the Charleux oil-droplet sign on distant-direct ophthalmoloscopy and scissoring of reflexes on retinoscopy. ${ }^{9}$ However, these classical signs may be difficult to interpret in localised inferior corneal thinning as observed in PMD. The inferior pear-shaped reflex observed on distant indirect ophthalmoscopy is a useful aid to establish a bedside clinical diagnosis of inferior ectasia in the current COVID-19 era, where direct ophthalmoscopy is avoided and a comprehensive topographical assessment may not be immediately feasible. Previously, we have described utility of distant indirect ophthalmoscopy as a modification of Bruckner's test to diagnose gross refractive errors and localised corneal changes. ${ }^{10-12}$ Similarly, we propose the same can be done for screening corneal ectasias, as shown in our case. Although not specific, the test is sensitive to screen gross curvatural changes occurring in cornea, which may prove helpful and safe in these pandemic times where there is reluctance to use common close contact machines.

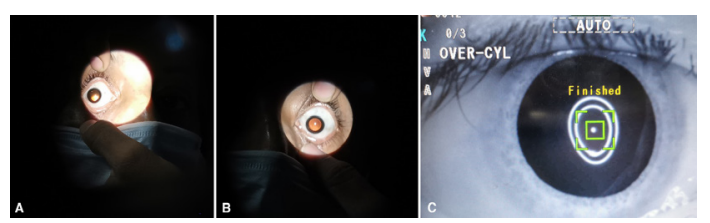

Figure 1 Distant indirect ophthalmoscopy reflex in (A) right eye showing a pear-shaped bright area inferiorly, (B) left eye showing diffuse bright illumination. (C) Mires in right eye on autorefractometer which are vertically oval and most compressed in 4 o'clock and 8 o'clock meridians. 

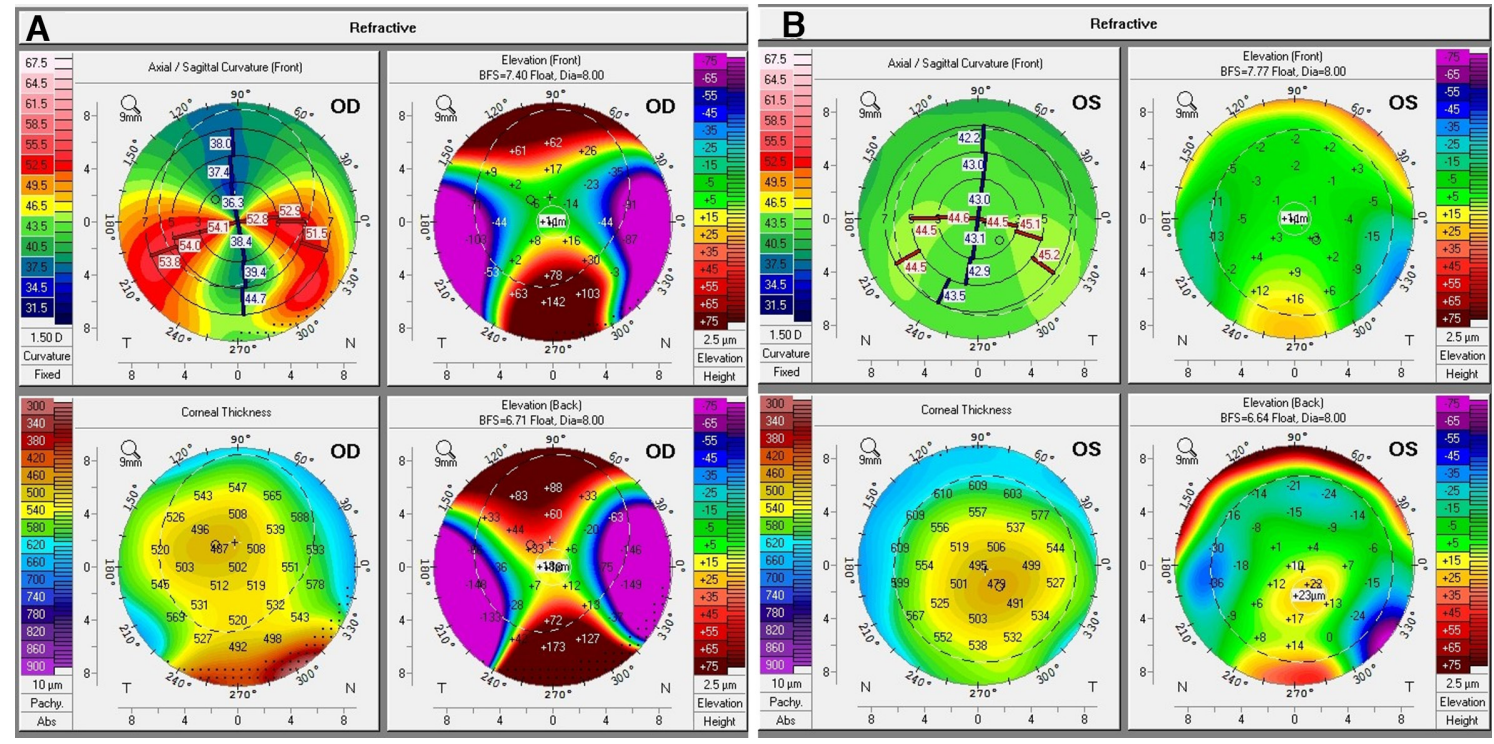

Figure 2 Refractive four maps Pentacam of (A) right eye showing crab-claw pattern of corneal steepening with against the rule astigmatism and inferior thinned pachymetry, (B) left eye showing evolving crab-claw pattern of corneal steepening with minimal against the rule astigmatism.

\section{Learning points}

- Proximity procedures should be avoided during these COVID-19 times.

- Distant indirect ophthalmoscopy is a reliable screening method for corneal ectatic disorders during these times where immediate topography is not feasible.

Contributors $A A B$ - diagnosis, preparation of manuscript. MK —editing of manuscript. SVA — editing of manuscript. AK—retrieval of data, review of literature.

Funding The authors have not declared a specific grant for this research from any funding agency in the public, commercial or not-for-profit sectors.

Competing interests None declared.

Patient consent for publication Obtained.

Provenance and peer review Not commissioned; externally peer reviewed.

\section{ORCID iD}

Amber Amar Bhayana http://orcid.org/0000-0002-0770-601X

\section{REFERENCES}

1 Krachmer JH. Pellucid marginal corneal degeneration. Arch Ophthalmol 1978:96:1217-21.

2 Basak SK, Hazra TK, Bhattacharya D, et al. Unilateral pellucid marginal degeneration. Indian J Ophthalmol 2000;48:233.

3 Koc M, Tekin K, Inanc M, et al. Crab claw pattern on corneal topography: pellucid marginal degeneration or inferior keratoconus? Eye 2018:32:11-18.

4 Peng Y, Zhou Y-H. Is novel coronavirus disease (COVID-19) transmitted through conjunctiva? J Med Virol 202010.1002/jmv.25753. [Epub ahead of print: 16 Mar 2020].

5 Li J-PO, Lam DSC, Chen Y, et al. Novel coronavirus disease 2019 (COVID-19): the importance of recognising possible early ocular manifestation and using protective eyewear. Br J Ophthalmol 2020;104:297-8.

6 Romano MR, Montericcio A, Montalbano C, et al. Facing COVID-19 in ophthalmology department. Curr Eye Res 2020;45:653-8.

7 Arabi YM, Murthy S, Webb S. COVID-19: a novel coronavirus and a novel challenge for critical care. Intensive Care Med 2020;46:833-6.

8 Gupta PC, Kumar MP, Ram J. COVID-19 pandemic from an ophthalmology point of view. Indian J Med Res 2020;151:411-8.

9 Vazirani J, Basu S. Keratoconus: current perspectives. Clin Ophthalmol 2013;7:2019-30.

10 Bhayana AA. Using Bruckner's test for gross keratometry screening. Indian J Ophthalmol 2019;67:1175.

11 Bhayana AA, Prasad P, Azad SV. Refractive errors and the red reflex- Bruckner test revisited. Indian J Ophthalmol 2019;67:1381-2.

12 Bhayana AA. Response to comments on: using Brückner's test for gross keratometry screening. Indian J Ophthalmol 2020;68:263.

Copyright 2020 BMJ Publishing Group. All rights reserved. For permission to reuse any of this content visit

https://www.bmj.com/company/products-services/rights-and-licensing/permissions/

BMJ Case Report Fellows may re-use this article for personal use and teaching without any further permission.

Become a Fellow of BMJ Case Reports today and you can:

- Submit as many cases as you like

- Enjoy fast sympathetic peer review and rapid publication of accepted articles

- Access all the published articles

- Re-use any of the published material for personal use and teaching without further permission

Customer Service

If you have any further queries about your subscription, please contact our customer services team on +44 (0) 2071111105 or via email at support@bmj.com.

Visit casereports.bmj.com for more articles like this and to become a Fellow 